\title{
HUBUNGAN KETERSEDIAAN ALAT KONTRASEPSI TERHADAP PENGGUNAAN ALAT KONTRASEPSI PADA PASANGAN USIA SUBUR
}

\author{
Andesma Saputra ${ }^{1}$, Leni Novianti ${ }^{2}$ \\ 1.Dosen Program Studi Ilmu Keperawatan, Universitas Kader Bangsa Palembang \\ 2. Dosen Program Studi Kesehatan Masyarakat, Universitas Kader Bangsa Palembang \\ andesmasaputraaizen@gmail.com \\ leninoviantileni71@gmail.com
}

\begin{abstract}
ABSTRAK
Perserikatan Bangsa Bangsa (PBB) memprediksi jumlah penduduk dunia pada 2017 sebanyak 7,6 miliar jiwa dan akan mencapai 8,6 miliar pada 2030. Program Keluarga Berencana (KB) yang digalakkan oleh pemerintah menjadi sangat penting sebagai pengendalian peledakan penduduk. Ketersediaan alat kontrasepsi menjadi faktor paling dominan pada penggunaan alat kontrasepsi pada ibu pasangan usia subur.Tujuan Penelitian ini adalah ingin mengetahui hubungan ketersediaan alat kontrasepsi terhadap pemilihan alat kontrasepsi pada PUS di wilayah kerja Puskesmas Tungkal Bengkulu Selatan tahun 2019. Metode yang digunakan dalam penelitian ini adalah survey analitik dengan pendekatan cross sectional. Populasi dalam penelitian ini adalah jumlah ibu pasangan usia subur (PUS) yang tercatat di Puskesmas Tungkal Bengkulu Selatan. Penelitian dilaksanakan pada tanggal 17 Februari - 29 Juli 2019. Sampel penelitian ini sebanyak 80 responden yang diambil dengan cara systematic random sampling. Data dianalisis dengan menggunakan analisis univariat dan bivariat dengan menggunakan uji statistik Chi-Square dengan tingkat kemanaknaan $\alpha=0,05$. Hasil penelitian bivariat menunjukkan ada hubungan yang bermakna antara ada hubungan antara ketersediaam alat kontrasepsi dengan penggunaan alat kontrasepsi $(\rho=0,002)$. Diharapkan dapat mengembangakan pelayanan bagi tenaga kesehatan di Puskesmas Tungkal Bengkulu Selatan khususnya di bagian KB/KIA untuk memberikan asuhan kebidanan secara komprehensif dalam upaya peningkatan kualitas pelayanan KB.
\end{abstract}

Kata Kunci : Ketersediaan Alat Kontrasepsi, Pemilihan Alat Kontrasepsi

\begin{abstract}
The United Nations (UN) predicts the world population in 2017 at 7.6 billion people and will reach 8.6 billion in 2030. The Family Planning Program (KB) which is promoted by the government is very important as controlling population explosion. The purpose of this study was to find out the relationship between ease of service, technical ability of officers, interpersonal relations, accuracy of family planning services, and the availability of contraceptives on the use of contraceptives PUS in the Health Center in Tungkal Bengkulu Selatan in 2019. The method used in this study was a survey analytic with cross sectional approach. The population in this study is the number of women from January -July 2019 who are registered at the Health Center in Tungkal Bengkulu Selatan. The sample of this study was 80 respondents taken by systematic random sampling. Data were analyzed using univariate and bivariate analysis using Chi-Square statistical tests with a significance level $\alpha=0.05$. The results of the bivariate study showed that there was a significant relationship between the availability of contraceptives and the use of contraceptives $(\rho=0.002)$. It is expected to develop services for health workers in the South Bengkulu Tungkal Health Center, especially in the KB / KIA section to provide comprehensive midwifery care in an effort to improve the quality of family planning services.
\end{abstract}

Keywords : Availability of contraception, Use of contraception 


\section{PENDAHULUAN}

Perserikatan Bangsa Bangsa (PBB) memprediksi jumlah penduduk dunia pada 2017 sebanyak 7,6 miliar jiwa dan akan mencapai 8,6 miliar pada 2030. Kemudian pada 2050 akan meningkat menjadi 9,8 miliar dan kembali bertambah menjadi 11,18 miliar pada 2100. Penduduk Indonesia pada tahun 2017 mencapai 255,5 juta. Kondisi ini menyebabkan Indonesia menduduki posisi keempat negara dengan jumlah penduduk terbanyak di dunia, dan posisi pertama di Asia Tenggara (BKKBN, 2015).

Program Keluarga Berencana (KB) yang digalakkan oleh pemerintah menjadi sangat penting sebagai pengendalian peledakan penduduk. Data Badan Kependudukan dan Keluarga Berencana Nasional (BKKBN) pada tahun 2013 mendapatkan 8.500.247 Pasangan usia subur(PUS) yang merupakan peserta KB baru, dengan rincian pengguna kontrasepsi suntik 4.128.115 peserta $(48,56 \%)$, pil 2.261.480 peserta $(26,60 \%)$, implan 784.215 peserta $(9,23 \%)$, kondom 517.638 peserta $(6,09 \%)$, alat kontrasepsi dalam rahim (AKDR) 658.632 peserta $(7,75 \%)$, metode operasi wanita (MOW) 128.79 peserta $(1,52 \%)$, metode operasi pria (MOP) 21.374 peserta $(0,25 \%)$ (Sinta, 2015).

Buku Profil Dinkes Bengkulu tahun 2018 diketahui jumlah Akseptor KB aktif di Bengkulu dengan MKJP sebanyak 56.517 (14\%), dengan jenis alat kontrasepsi MKJP terbanyak adalah implant sebanyak 37.554 (14\%). Sedangkan jumlah akseptor KB aktif non MKJP sebanyak 207.275 (79\%) dengan jenis kontrasepsi terbanyak adalah suntik yaitu 141.541 (54\%). Sedangkan peserta KB baru dengan MKJP 2.405 (15\%) dengan jenis alat kontrasepsi terbanyak implant 1.757 (11\%) dan non MKJP $13.683(84 \%)$ dengan jenis alat kontrasepsi terbanyak suntik $10.260(63 \% /$ dan pil 2.451 (15\%) (Profil Dinkes Bengkulu, 2018).

Pencapaian akseptor KB aktif di Kecamatan Pino Raya pada tahun 2018 adalah $70 \%$ akseptor KB memilih kontrasepsi non MKJP dan 32,2\% akseptor KB memilih kontrasepsi MKJP (Profil Dinas Kesehatan Bengkulu Selatan, 2018). Laporan pencapaian akseptor $\mathrm{KB}$ di Kampung KB Desa Pasar Pino pada tahun 2018 yaitu suntik $42,5 \%$, pil $19 \%$, kondom 2,9\%, IUD 17,5\%, dan implant $8 \%$ (Puskesmas Tungkal Bengkulu Selatan, 2018). Dari data periode Januari sampai Maret 2019 di Kampung KB desa Pasar Pino terdapat 424 jumlah pasangan usia subur. Didapatkan juga data jumlah yang menggunakan kontrasepsi suntik 47,16\%, pil $27,35 \%$, implant $17,45 \%$, kondom $4,71 \%$, dan IUD 3,30\% (Data Kampung KB, 2019).

\section{Pelayanan KB dikatakan} berkualitas apabila memenuhi beberapa unsur pelayanan, yaitu: ketersediaan pilihan metode kontrasepsi, informasi yang diberikan kepada klien, kemampuan perugas pelayanan $\mathrm{KB}$, hubungan interpersonal, mekanisme untuk mendorong pelayanan lanjutan dan ketepatan atau kesesuaian pemberi pelayanan. Fokus pada kualitas pelayanan menjadi penting dengan kelangsungan penggunaan kontrasepsi sebagai salah satu dari hasil kualitas pelayanan (Bruce cit Amalia, 2014).

Penelitian ini diharapkan dapat mengetahui hubungan antara ketersediaan alat kontrasepsi terhadap penggunaan alat kontrasepsi pada PUS di wilayah kerja Puskesmas Tungkal Bengkulu Selatan 
khususnya Kampung KB Desa Pasar Pino

Bengkulu Selatan tahun 2019.

\section{METODE}

\section{Desain penelitian}

Jenis penelitian ini adalah kuantitatif dengan menggunakan survey analitik dengan pendekatan cross sectional yaitu suatu penelitian yang semua variabelnya, baik variabel dependen (penggunaan alat kontrasepsi) maupun independen (ketersediaan alat kontrasepsi).

\section{Populasi dan sampel}

\section{Populasi}

Penelitian ini dilaksanakan di wilayah kerja Puskesmas Tungkal Bengkulu Selatan. Penelitian ini dilaksanakan selama 1 (satu) semester tahun 2019. Populasi dalam penelitian ini adalah seluruh ibu PUS yang tercatat di wilayah kerja Puskesmas Tungkal Bengkulu Selatan dari bulan Januari-Juli 2019 yang berjumlah 432 orang.

\section{Sampel}

Berdasarkan perhitungan sampel dalam penelitian ini sebanyak 80 orang dari seluruh total populasi. Sampel yang diambil berdasarkan teknik yaitu systematic random sampling.

\section{Tempat dan Waktu penelitian}

Penelitian telah dilakukan di wilayah kerja Puskesmas Tungkal Bengkulu Selatan pada tangggal 17 Februari - 29 Juli 2019 di Kampung KB Desa Pasar Pino Bengkulu Selatan.

\section{HASIL PENELITIAN}

1. Analisis Univariat

a. Penggunaan Alat Kontrasepsi pada Ibu Pasangan Usia Subur

Tabel 1.

Distribusi Frekuensi Berdasarkan Penggunaan Alat Kontrasepsi pada Ibu Pasangan Usia Subur

\begin{tabular}{|c|c|c|c|}
\hline No & $\begin{array}{c}\text { Penggun } \\
\text { aan Alat } \\
\text { Kontrase } \\
\text { psi } \\
\end{array}$ & $\begin{array}{c}\text { Frekue } \\
\text { nsi } \\
\text { (n) }\end{array}$ & $\begin{array}{c}\text { Persenta } \\
\text { se }(\%)\end{array}$ \\
\hline 1 & $\mathrm{Ya}$ & 53 & 66,2 \\
\hline 2 & Tidak & 27 & 33,8 \\
\hline \multicolumn{2}{|r|}{ Jumlah } & 80 & 100 \\
\hline
\end{tabular}

Berdasarkan tabel 1. menunjukkan bahwa dari 80 responden yang diteliti, sebanyak 53 responden $(66,2 \%)$ yang menggunakan alat kontrasepsi, lebih banyaak dibandingkan dengan yang tidak menggunakan alat kontrasepsi sebanyak 27 responden $(33,8 \%)$.

\section{b. Ketersediaan Alat Kontrasepsi}

Tabel 2.

Distribusi Frekuensi Berdasarkan Ketersediaan Alat Kontrasepsi

\begin{tabular}{|c|c|c|c|}
\hline No & $\begin{array}{c}\text { Ketersed } \\
\text { iaan Alat } \\
\text { Kontrase } \\
\text { psi } \\
\end{array}$ & $\begin{array}{c}\text { Frekue } \\
\text { nsi } \\
\text { (n) }\end{array}$ & $\begin{array}{l}\text { Persent } \\
\text { ase }(\%)\end{array}$ \\
\hline 1 & Tersedia & 42 & 52,5 \\
\hline 2 & $\begin{array}{c}\text { Tidak } \\
\text { Tersedia }\end{array}$ & 38 & 47,5 \\
\hline \multicolumn{2}{|r|}{ Jumlah } & 80 & 100 \\
\hline
\end{tabular}

Berdasarkan tabel 2. menunjukkan dari 80 responden yang diteliti, yang tersedia sebanyak 42 responden $(52,5 \%)$ lebih banyak dibandingkan dengan yang tidak tersedia sebanyak 38 responden $(47,5 \%)$. 
Tabel 3.

Hubungan Ketersediaan Alat Kontrasepsi dengan Penggunaan Alat Kontrasepsi pada Ibu Pasangan Usia Subur

\begin{tabular}{|c|c|c|c|c|c|c|c|c|}
\hline \multirow{3}{*}{$\begin{array}{l}\mathbf{N} \\
\mathbf{0}\end{array}$} & \multirow{3}{*}{$\begin{array}{c}\text { Keterse } \\
\text { diaan } \\
\text { Alat } \\
\text { Kontras } \\
\text { epsi }\end{array}$} & \multicolumn{4}{|c|}{$\begin{array}{c}\text { Pemilihan Alat } \\
\text { Kontrasepsi }\end{array}$} & \multicolumn{2}{|c|}{$\begin{array}{c}\text { Jum la } \\
\text { h }\end{array}$} & \multirow{3}{*}{$\begin{array}{c}\text { p.val } \\
\text { ue }\end{array}$} \\
\hline & & \multicolumn{2}{|c|}{ Ya } & \multicolumn{2}{|c|}{ Tidak } & & & \\
\hline & & $\mathrm{n}$ & $\%$ & $\mathbf{n}$ & $\%$ & & & \\
\hline 1 & Tersedia & 35 & $\begin{array}{r}83 \\
3\end{array}$ & 7 & $\begin{array}{r}17 \\
5\end{array}$ & $\begin{array}{l}4 \\
2\end{array}$ & $\begin{array}{c}10 \\
0\end{array}$ & 0,002 \\
\hline 2 & $\begin{array}{c}\text { Tidak } \\
\text { Tersedia }\end{array}$ & 18 & $\begin{array}{r}47 \\
4\end{array}$ & $\begin{array}{l}2 \\
0\end{array}$ & $\begin{array}{r}52 \\
6\end{array}$ & $\begin{array}{l}3 \\
8\end{array}$ & $\begin{array}{c}10 \\
0\end{array}$ & \\
\hline & Total & 53 & & $\begin{array}{l}2 \\
7 \\
\end{array}$ & & $\begin{array}{l}8 \\
0 \\
\end{array}$ & & \\
\hline
\end{tabular}

Berdasarkan tabel 3. didapatkan bahwa dari 42 responden yang tersedia alat kontrasepsi sebanyak 35 responden $(83,3 \%)$ yang menggunakan alat kontrasepsi. Sedangkan dari 38 responden yang tidak tersedia alat kontrasepsi sebanyak 18 responden $(47,4 \%)$ yang menggunakan alat kontrasepsi. Hal ini menunjukkan bahwa responden yang tersedia alat kontrasepsi lebih banyak menggunakan alat kontrasepsi dibandingkan responden yang tidak tersedia alat kontrasepsi.

Berdasarkan hasil uji statistik dengan chi-square didapatkan $\mathrm{p}$-value = 0,002 , dimana $p$-value $(0,002)$ lebih kecil dari nilai $\alpha(0,05)$, maka ada hubungan yang bermakna antara ketersediaan alat kontrasepsi dengan penggunaan alat kontrasepsi pada ibu pasangan usia subur di Kampung KB Desa Pasar Pino Bengkulu Selatan Tahun 2019. Dengan demikian hipotesis yang menyatakan bahwa ada hubungan yang bermakna antara antara ketersediaan alat kontrasepsi dengan penggunaan alat kontrasepsi pada ibu pasangan usia subur terbukti secara statistik.
Berdasarkan hasil analisis keeratan hubungan diperoleh nilai cohort didapatkan 5,556 artinya responden yang tersedia alat kontrasepsi mempunyai peluang 5,5 kali menggunakan alat kontrasepsi dibandingkan dengan responden yang tidak tersedia alat kontrasepsi.

\section{PEMBAHASAN}

\section{Pembahasan Univariat}

\section{a. Penggunaan Alat Kontrasepsi}

Penelitian ini dilakukan pada 80 responden ibu pasangan usia subur di Kampung KB Desa Pasar Pino Bengkulu Selatan tahun 2019, dibagi menjadi dua kategori yaitu ya (jika ibu menggunakan alat kontrasepsi) dan tidak (jika ibu tidak menggunakan alat kontrasepsi).

Berdasarkan hasil analisis univariat didapatkan dari 80 responden yang diteliti, sebanyak 53 responden $(66,2 \%)$ yang menggunakan alat kontrasepsi, lebih banyaak dibandingkan dengan yang tidak menggunakan alat kontrasepsi sebanyak 27 responden $(33,8 \%)$.

Hasil penelitian ini sejalan dengan Bruce cit Amalia (2014) bahwa pelayanan KB dikatakan berkualitas apabila memenuhi beberapa unsur pelayanan, yaitu: ketersediaan pilihan metode kontrasepsi, informasi yang diberikan kepada klien, kemampuan perugas pelayanan $\mathrm{KB}$, hubungan interpersonal, mekanisme untuk mendorong pelayanan lanjutan dan ketepatan atau kesesuaian pemberi pelayanan. Fokus pada kualitas pelayanan menjadi penting dengan kelangsungan penggunaan kontrasepsi sebagai salah satu dari hasil kualitas pelayanan.

Berdasarkan hasil penelitian, teori dan penelitian terkait peneliti berasumsi bahwa berfokus pada kualitas pelayanan 
kotrasepsi pada pasangan usia subur (PUS) yaitu pada penggunaan alat kontrasepsi.

\section{b. Ketersediaan alat}

Berdasarkan hasil analisis univariat menunjukkan dari 80 responden yang diteliti, yang tersedia sebanyak 42 responden $(52,5 \%)$ lebih banyak dibandingkan dengan yang tidak tersedia sebanyak 38 responden $(47,5 \%)$.

Hasil penelitian ini sejalan dengan teori yang mengatakan bahwa Ketersediaan alat kontrasepsi, dimana ketersediaan alat/obat KB menjadi bagian utama yang harus dimiliki pos-pos pelayanan KB sesuai dengan metode kontrasepsi yang akan diberikan. Keberhasilan pelayanan KB ditentukan oleh beberapa unsur salah satunya sarana prasarana yang memenuhi standar baku pelayanan (BKKBN, 2014).

Berdasarkan hasil penelitian dan teori terkait peneliti berasumsi bahwa keberhasilan pelayanan $\mathrm{KB}$ terdapat pada ketersediaat alat dan sarana prasara yang memenuhi standar pelayanan.

\section{Pembahasan Bivariat}

Hubungan antara Ketersediaan Alat Kontrasepsi dengan Penggunaan Alat Kontrasepsi pada Ibu Pasangan Usia Subur

Berdasarkan hasil analisis bivariat
dapat dilihat bahwa dari 42 responden
yang tersedia alat kontrasepsi sebanyak 35
responden $(83,3 \%)$ yang menggunakan alat
kontrasepsi. Sedangkan dari 38 responden
yang tidak tersedia alat kontrasepsi
sebanyak 18 responden (47,4\%) yang
menggunakan alat kontrasepsi. Hal ini
menunjukkan bahwa responden yang
tersedia alat kontrasepsi lebih banyak
menggunakan alat kontrasepsi

dibandingkan responden yang tidak tersedia alat kontrasepsi.

Berdasarkan hasil uji statistik dengan chi-square didapatkan $p$-value $=$ 0,002 , dimana $p$-value $(0,002)$ lebih kecil dari nilai $\alpha(0,05)$, maka ada hubungan antara ketersediaan alat kontrasepsi dengan penggunaan alat kontrasepsi pada ibu pasangan usia subur di Kampung KB Desa Pasar Pino Bengkulu Selatan Tahun 2019. Dengan demikian hipotesis yang menyatakan bahwa ada hubungan antara antara ketersediaan alat kontrasepsi dengan penggunaan alat kontrasepsi pada ibu pasangan usia subur terbukti secara statistik.

Berdasarkan hasil analisis keeratan hubungan diperoleh nilai Odds Ratio (OR) didapatkan 5,556 artinya responden yang tersedia alat kontrasepsi mempunyai peluang 5,5 kali menggunakan alat kontrasepsi dibandingkan dengan responden yang tidak tersedia alat kontrasepsi.

Penelitian ini sejalan dengan teori yang mengatakan bahwa Ketersediaan alat kontrasepsi, dimana ketersediaan alat/obat KB menjadi bagian utama yang harus dimiliki pos-pos pelayanan $\mathrm{KB}$ sesuai dengan metode kontrasepsi yang akan diberikan. Keberhasilan pelayanan $\mathrm{KB}$ ditentukan oleh beberapa unsur salah satunya sarana prasarana yang memenuhi standar baku pelayanan (BKKBN, 2014).

Penelitian ini sejalan dengan penelitian Muhammad (2013) bahwa alat kontrasepsi selalu tersedia, lebih banyak memilih alat kontrasepsi suntik (94,2\%) sedangkan responden yang mengatakan bahwa alat kontrasepsi tidak tersedia, lebih banyak memilih alat kontrsepsi non suntik $(16,4 \%)$. Ada hubungan antara ketersediaan alat kontrasepsi dengan 
penggunaan metode kontrasepsi suntik ( $p=$ 0,016).

Berdasarkan hasil penelitian, teori, dan penelitian terdahulu maka peneliti berpendapat bahwa ada hubungan yang bermakna antara ketersediaan alat kontrasepsi dengan penggunaan alat kontrasepsi pada ibu pasangan usia subur di Kampung KB Desa Pasar Pino Bengkulu Selatan Tahun 2019. Ketersediaan pelayanan alat kontrasepsi terwujud dalam bentuk tersedia atau tidaknya fasilitas atau sarana kesehatan (tempat pelayanan kontrasepsi) yang dapat digunakan oleh PUS. Ketika menurunnya ketersediaan alat kontrasepsi di sumber pelayanan pemerintah sehingga konsumen terpaksa harus memperoleh pelayanan dari swasta. Kecenderungan ini merugikan keluarga miskin atau kurang mampu karena mereka tidak mampu menjangkau pelayanan KB dari sektor swasta, sedangkan jumlah pelayanan kontrasepsi yang murah oleh pemerintah terbatas. Dari sisi klien, hal ini dapat disebabkan oleh ketidakmampuan penduduk untuk membayar harga kontrasepsi yang cenderung mahal. Ketersediaan alat kontrasepsi yang cukup, mudah dan murah memberikan kesempatan kepada akseptor menggunakan kontrasepsi yang sesuai dengan kondisi fisik dan kesehatannya. Kebutuhan alat kontrasepsi yang besar, jika tidak diimbangi dengan penyediaan alat kontrasepsi yang cukup akan mengancam kelangsungan penggunaan alat kontrasepsi.

Berdasarkan penelitian diatas maka dapat disimpulkan bahwa faktor ketersediaan alat kontrasepsi kemungkinan sebagai faktor yang paling berhubungan dengan penggunaan alat kontrasepsi pada ibu pasangan usia subur. Ketersediaan alat kontrasepsi merupakan suatu kondisi dimana pelayanan yang ditawarkan sesuai dengan SOP sehingga dapat diterima dan mampu membuat pemakai pelayanan tersebut merasa puas sesuai dengan kebutuhannya. Betapapun sulitnya kebutuhan pelayanan tersebut dipenuhi, waktu dan tempat pelayanan ditawarkan (BKKBN, 2014).

Berdasarkan hasil penelitian, peneliti berpendapat bahwa ketersediaan alat kontrasepsi menjadi faktor paling dominan pada penggunaan alat kontrasepsi pada ibu pasangan usia subur karena jika semua pilihan alat kontrasepsi tersedia dipelayanan kesehatan sesuai dengan pilihan dan kebutuhan akseptor maka mereka cenderung akan menggunakan alat kontrasepsi. Hal ini juga dikarenakan meskipun ibu mendapatkan kemudahan dalam pelayanan $\mathrm{KB}$, petugas yang ditemui kemampuan teknis nya baik, hubungan interpersonal ibu dan petugas baik, dan ibu juga tepat dalam mendapatkan pelayanan $\mathrm{KB}$ namun jika alat kontrasepsi yang sesuai dan dibutuhkan oleh ibu tidak tersedia maka itu akan memicu ibu untuk tidak menggunakan alat kontrasepsi.

\section{KESIMPULAN}

Berdasarkan hasil penelitian yang telah dilakukan maka diperoleh kesimpulan bahwa ada hubungan ketersediaan alat kontrasepsi dengan penggunaan alat kontrasepsi pada Ibu Pasangan Usia Subur di wilayah kerja Puskesmas Tungkal Bengkulu Selatan khususnya Kampung KB Desa Pasar Pino Bengkulu tahun 2019. Ketersediaan alat kontrasepsi menjadi faktor paling dominan pada penggunaan alat kontrasepsi pada ibu pasangan usia subur. 
SARAN

Diharapkan untuk penelitian ini dapat digunakan sebagai bahan informasi dalam mengembangakan pelayanan bagi tenaga kesehatan di Puskesmas Tungkal Bengkulu Selatan khususnya di bagian KB/KIA untuk memberikan asuhan secara komprehensif dalam upaya peningkatan kualitas pelayanan KB. Untuk penelitian selanjutnya menggunakan metode pengukuran, teknologi dan informasi yang berbeda.

\section{DAFTAR PUSTAKA}

Amalia,L.2015. Faktor-Faktor Yang Mempengaruhi Ibu Dalam Memilih alat kontrasepsi. Skripsi Universitas Negeri Gorontalo

Arsyaningsih N., Suhartono., Suherni T., 2014. Analisis Faktor Yang Mempengaruhi Kualitas Pelayanan Konseling Keluarga Berencana Alat Kontrasepsi Dalam Rahim Oleh Bidan Di Wilayah Kerja Puskesmas Wiradesa Kabupaten Pekalongan Tahun 2013. Jurnal Kebidanan. Vol 3. No 7.

Asih, L,. Oesman, H. 2015. Analisis Lanjut SDKI 2007: Faktor yang mempengaruhi pemakaian kontrasepsi jangka panjang $(M K J P)$. Jakarta: BKKBN

BKKBN. 2013. Rencana Aksi Nasional Pelayanan Keluarga Berencana 2014-2015. Jakarta: Kemenkes RI.

2014. Petunjuk Pelaksanaan Program KB. Jakarta: BKKBN

2015. Jumlah Peserta KB Aktif Menurut Metode Kontrasepsi Cara Modern : Data tahun 2014.
Bengkulu : Dinas Kesehatan Provinsi Bengkulu.

2015.PBB Proyeksikan Penduduk Dunia Mencapai 8,5 Pada Tahun 2030. Jakarta: Jakarta.

2018. Pedoman Pelayanan KB Pasca Persalinan di Fasilitas Kesehatan : Jenis-jenis Metode Kontrasepsi. Jakarta : Badan Koordinasi Keluarga Berencana.

Bruce, J. 1990. Fundamental elements of the quality of care: a simpel Frame work. Stud Fam Plann. hlm. 61-91

Hong, R., Montana, L., Mishra V. 2016. Family planning services quality as a determinant of use of IUD in Egypt. BMC

Kemenkes RI. Situasi dan Analisis Keluarga Beerencana. Jakarta: Kemenkes; 2017.

Mahmudah., Laras T.N. 2015. Analisis Faktor Yang Berhubungan Dengan Pemilihan Metode Kontrasepsi Jangka Panjang (MKJP) Pada Akseptor KB Wanita Di Kecamatan Banyu Biru Kabupaten Semarang.Unnes Journal of Public Health (2) (2015).

Muhammad, R. 2013. Faktor yang berhubungan dengan pemilihan metode kontrasepsi suntik di kelurahan mattoangin kecamatan mariso kota Makassar. Media Kesehatan Masyarakat Indonesia. Vol 9, No 3.

Puskesmas Tungkal Bengkulu Selatan. 2018. Rekam Medis. Puskesmas Tungkal Bengkulu Selatan

Profil Dinas Kesehatan Provinsi Bengkulu tahun 2018. 
Sari. I.P. 2012. Analisis Kualitas Pelayanan $K B \quad$ terhadap Kelangsungan Pemakaian Kontrasepsi Hormonal di Indonesia. Depok: Tesis Fakultas Kesehatan Masyarakat Universitas Indonesia.

Sinta, N. 2015. Hubungan antara Kualitas Pelayanan KB oleh Bidan dengan Pemilihan Metode Kontrasepsi Jangka Panjang (MKJP) pada Akseptor KB Baru di Kabupaten Bogor. Poltekkes Kemenkes Bandung

WHO (World Health Organization), 2014. Perencanaan Keluarga Berencana Geneva: Swiss. 